\title{
Brief In Vitro Analysis on Improvement of Available Phosphorous In Low Soluble Eppawala Rock Phosphate
}

Rhan $\mathrm{H}^{*}$ and Walpola BC

Department of Soil Science, University of Ruhuna, Sri Lanka

\begin{abstract}
Rock Phosphate (RP) is any naturally occurring geological material that contains one or more phosphate minerals suitable for commercial use. There is a major RP deposit in Eppawala, Sri Lanka and this RP identify as Eppawala Rock Phosphate (ERP). Large proportion of soluble inorganic phosphate added to soil is rapidly fixed as insoluble forms soon after application. Development of an economical and environmentally friendly alternative for successful soil $\mathrm{P}$ management is major concern in crop production and Phosphate Solubilizing Microorganism (PSM) attracted attention in this regard. This study was conducted to identify the Phosphorus solubilizing bacteria. Soil samples were collected from different Agricultural crop lands. Soil were Spread cultured in NBRIP medium after a serial dilution. The bacterial colonies that produced clear zone of activity were considered as potential phosphate solubilizes. They were sub-cultured for the further purification. The experiment has been carried out adding $28 \% \mathrm{P} 2 \mathrm{O} 5$ containing Eppawala Rock Phosphate with NBRIP medium. Bacterial growth in 660 wave length by using shimadzu UV spectrophotometer, $\mathrm{P}$ solubilization, and $\mathrm{pH}$ were measured respectively $1,3,5$ and 7 days after inoculation. Clear zone producing bacteria in phosphate enriched medium has been selected as $\mathrm{P}$ solubilizing bacteria with time period all bacterial strains has shown improvement of solubilized $\mathrm{P}$ in the culture media. Among them PSB-7 strain has shown a vigorous growth and maximum P Solubilization $237.61 \mathrm{ppm}$ in vitro during experiment. Despite of environment unfriendly chemical solubilization methods of naturally existing Rock Phosphate this biological solubilization generate maximum amount of plant available phosphorous.
\end{abstract}

Keywords: Insoluble rock phosphate; Phosphorus solubilizing microorganisms; Biological solubilization; Environment friendly crop improvement and biofertilizer

\section{Introduction}

Rock Phosphate (RP) contains one or more phosphate minerals suitable for commercial use. The term RP is globally accepted but not precise describing any naturally occurring geological material. Most of the world's phosphate fertilizers are produced from RP resources and almost all of these resources contain some form of mineral apatite $[1,2]$. There is a major RP deposit and occurrence in Eppawala in Anuradhapura district in Sri Lanka. This RP identify as Eppawala Rock Phosphate (ERP). The ERP deposit display some feature of a sedimentary phosphate secondary deposit formed over parent carbonatite rock [3,4]. The effectiveness of the direct application of RP depends on the following factors mineralogical composition of RP $[5,6]$. Soil physicochemical properties and the cultivated crop $[7,8]$. When considering natural RP deposits only a small percentage of the total phosphorous available to plants out of the total phosphorous of the RP deposit [1,9]. Although RP solubilization rarely occurs in nonacidic soils, it may occur when these soils are deficient in exchangeable $\mathrm{Ca}$, because this characteristic enhances P solubilization [10]. Although a large proportion of soluble inorganic phosphate added to soil is rapidly fixed as insoluble forms soon after application and becomes unavailable to plants [11]. Next to nitrogen Phosphorous is an essential macronutrient for the plant growth and development [12]. To increase P content in soil ERP solubilization is being done by lowering of soil $\mathrm{pH}$ by using chemical solubilization but this is not environmentally viable $[13,14]$.

Many soils used for agriculture are infertile with low levels of essential plant nutrients. The key components of the soil-plant system is microbial populations where they are immersed in a interactions affecting plant development $[10,15]$. The application of efficient microbial inoculants and slow release fertilizers, like RP are low input technological practices which might lead to the development of sustainable soil plant systems [16].
The insoluble phosphate is expected to convert plant available form of Phosphate by enhancement of multification of beneficial microbes and the P solubilizing organisms present in the soil to react with RP [4,17]. It is well known that many microorganisms isolated from the soil are able to dissolve different kinds of rock phosphates in a liquid culture $[18,19]$. Phosphate Solubilizing Microorganism (PSM) specially Phosphate solubilizing bacteria attracted attention in this regard development of an economical and environmentally friendly alternative for successful soil P management is major concern in crop production [20,21].

It's generally accepted that there are three major mechanism of the mineral phosphate solubilization. The first one is release of complexing or mineral dissolving compounds like organic acid anions, siderophores, protons, hydroxyl ions, $\mathrm{CO}_{2}$. Second one is liberation of extracellular enzymes by biochemical $\mathrm{P}$ mineralization. The third one is release of $\mathrm{P}$ during substrate degradation by biological $\mathrm{P}$ mineralization $[1,10,18,22]$. Some identified PSB namely Achromobacter sp, Aerobacter sp., Agrobacterium tumefaciens, Bacillus sp., Enterobacter sp., Pseudomonas sp., Serrtia sp., Brevibacterium sp., Burkholderia sp.

In spite of the number of studies already done, further research is needed to differentiate clearly the ability of $\mathrm{P}$ solubilizing bacteria to solubilization of ERP.

*Corresponding author: Rhan $\mathrm{H}$, Department of Soil Science, University of Ruhuna, Sri Lanka, Tel: 041-2222681/2222682; Fax: 041-2227001; E-mail: nuwanrha@gmail.com

Received May 16, 2017; Accepted May 31, 2017; Published June 07, 2017

Citation: Rhan H, Walpola BC (2017) Brief In Vitro Analysis on Improvement of Available Phosphorous In Low Soluble Eppawala Rock Phosphate. J Microb Biochem Technol 9:105-108. doi: 10.4172/1948-5948.1000351

Copyright: @ $2017 \mathrm{Rhan} \mathrm{H}$, et al. This is an open-access article distributed under the terms of the Creative Commons Attribution License, which permits unrestricted use, distribution, and reproduction in any medium, provided the original author and source are credited. 


\section{Materials and Methods}

\section{Rhizospheric soil sampling}

The soil samples were collected from rhizosphere, near to the root zone of the plants. About 45 soil samples were collected for the purpose of bacteria isolation. They were collected from different Agricultural crop lands of Sri Lanka including terrestrial, aqua and swamp regions including Matara, Galle and Hambantota districts of Sri Lanka by using opportunity sampling method.

\section{Phosphate solubilizing bacteria (PSB) isolation}

The collected soil samples were spread cultured in National Botanical Research Institute phosphate (NBRIP) medium after a serial dilution. A $10 \mathrm{~g}$ of soil sample of each sample was dissolved in $90 \mathrm{ml}$ of distilled sterilized water. Then $1 \mathrm{ml}$ of above soil solution was diluted in an aliquot of $9 \mathrm{ml}$ distilled water. This procedure was performed until $10^{-5}$ concentration of soil solution was obtained. The bacterial colonies which producing clear zones around the colony were known to be great phosphate solubilizes and they were sub cultured in the petri dishes which containing NBRIP for the purpose of further purification. Ten phosphate solubilizing bacteria were used which produced clear zone around the colony [18].

\section{Quantitative enumeration of bacteria}

The experiment has been carried out using $28 \% \mathrm{P}_{2} \mathrm{O}_{5}$ containing Eppawala Rock Phosphate as Eppawala phosphate deposit to represent different weathering stages and varying mineralogy [8].

After that isolated bacterial cultures were inoculated into NBRIP broth cultures ( $\mathrm{pH}=7.0$ ) which containing $500 \mathrm{ml}$ flasks of $250 \mathrm{ml}$ ERP instead of $\mathrm{Ca}_{3}\left(\mathrm{PO}_{4}\right)_{2}$. The composition of culture was $10 \mathrm{~g}$ glucose, 8.03 g ERP, $5 \mathrm{~g} \mathrm{MgCl}_{2}, 0.25 \mathrm{~g} \mathrm{MgSO}_{4} .7 \mathrm{H}_{2} \mathrm{O}, 0.2 \mathrm{~g} \mathrm{KCl}, 0.1 \mathrm{~g}\left(\mathrm{NH}_{4}\right)_{2} \mathrm{SO}_{4}$ in $1 \mathrm{~L}$ distilled water [23]. Except ERP all the chemicals used in this research was Analytical regents products of Daejung Chemicals \& Metals Co., Ltd. The samples containing flasks were kept in a rotary shaker at 150 rpm speed at $30^{\circ} \mathrm{C}$. There bacterial growth, $\mathrm{P}$ solubilisation and $\mathrm{pH}$ were measured respectively $1,3,5$ and 7 days after inoculation.

Bacterial growth was measured colorimetrically by using a spectrophotometer at $660 \mathrm{~nm}$ wavelength. The bacterial broth cultures were mixed with $1 \mathrm{~N} \mathrm{HCl}$ at $1: 1$ ratio and subjected to spectrophotometric measurements [24,25].

$\mathrm{P}$ solubilization was determined by using following procedure. About $10 \mathrm{ml}$ of bacterial solution was centrifuged at $10000 \mathrm{rpm}$. After that the solution was carefully taken into a colour development procedure. $\mathrm{P}$ absorptions were determined at $660 \mathrm{~nm}$ wavelength by using shimadzu uv spectrophotometer.

\section{Statistical Analysis}

Data were subjected to analysis of variance (ANOVA) using SAS [26]. The Duncans's Multiple Range Test (DMRT) was used to test the significance between treatment mean at $\mathrm{P}<0.05, \mathrm{P}<0.01$ and $\mathrm{P}<0.001$.

\section{Results and Discussion}

\section{Identification of phosphorus solubilizing bacteria}

Basically clear zone producing bacteria in a phosphate enriched medium has been selected as P solubilizing bacteria. They were transferred in to ERP enriched broth medium and those bacteria were monitored for $\mathrm{pH}$, growth and $\mathrm{P}$ solubilization.
Comparatively high solubilized $\mathrm{P}$ could be identified in an ERP solution. Normally around 5 ppm in an ERP solution. But after 7 days of introduction of PSB to the media the solubilized P is increasing to hundreds (Tables 1 and 2).

According to the Tables 1 and 2 it can be identified highest $\mathrm{P}$ solubilization in ERP medium at day 1 and 3 has been recorded by the PSB-12 (P>0.001). But in the day 5 and 7 it has changed the highest $\mathrm{P}$ solubilizer. In those days highest $\mathrm{P}$ solubilization has been recorded by the PSB-1 $(\mathrm{P}>0.001)$. At the day 1 lowest $\mathrm{P}$ solubilization has been recorded by the PSB-3. But in day 3 lowest $\mathrm{P}$ solubilization has been recorded by PSB-17 ( $>>0.001)$. In the both day 5 and 7 PSB-16 $(\mathrm{P}>0.001)$ has recorded the lowest $\mathrm{P}$ solubilization.

Considering about the bacterial growth it has been recorded that PSB-8 $(\mathrm{P}>0.001)$ has the highest growth rate. Though the Growth of the bacteria in a higher amount its $\mathrm{P}$ solubilization is in the $3 \mathrm{rd}$ of the raw. At the 3rd day the highest bacterial growth has recorded by PSB-1. Though it's the highest bacterial growth it's P solubilization not the highest at the same date. In the day 5 as well in the day 7 PSB-7 $(\mathrm{P}<0.001)$ has recorded the highest bacterial growth.

In the day 1 lowest bacterial growth has shown by the PSB-15 $(\mathrm{P}<0.001)$. In the day 3 PSB- 15 collaborates with PSB-3 to show the lowest bacterial growth. In the day 5 PSB-3 has shown the lowest growth in ERP medium. But in day 7 PSB-4, has shown the lowest bacterial growth.

Normally $\mathrm{P}_{2} \mathrm{O}_{5}$ content in Phosphate Rocks varies from 4.5-33\% mainly due to mineralogical genetic process [27]. Sri Lankan ERP

\begin{tabular}{|c|c|c|c|}
\hline & $\mathbf{P}$ & Growth & $\mathrm{pH}$ \\
\hline \multicolumn{4}{|l|}{ Day 1} \\
\hline PSB-1 & $14.59 \mathrm{~b}$ & $0.431 b$ & $3.98 \mathrm{~d}$ \\
\hline PSB-3 & $3.51 f$ & $0.151 \mathrm{ef}$ & $4.19 a$ \\
\hline PSB-4 & $9.90 d$ & $0.236 c$ & $3.82 d$ \\
\hline PSB-6 & $7.34 \mathrm{e}$ & $0.167 \mathrm{de}$ & $4.06 \mathrm{bc}$ \\
\hline PSB-7 & $14.09 b c$ & $0.252 c$ & $3.82 \mathrm{~d}$ \\
\hline PSB-8 & $12.70 c$ & $0.567 a$ & $3.83 d$ \\
\hline PSB-12 & $16.75 a$ & $0.252 c$ & $3.91 \mathrm{~d}$ \\
\hline PSB-16 & $7.61 \mathrm{e}$ & $0.200 \mathrm{~d}$ & $4.18 a b$ \\
\hline PSB-15 & $10.45 d$ & $0.128 f$ & $3.96 \mathrm{~cd}$ \\
\hline PSB-17 & $8.01 \mathrm{e}$ & 0.160 ef & $3.88 \mathrm{~d}$ \\
\hline Significance & $* * *$ & $* * *$ & $* * *$ \\
\hline CV\% & 9.26 & 7.78 & 1.74 \\
\hline \multicolumn{4}{|l|}{ Day 3} \\
\hline PSB-1 & $28.19 b c$ & $0.552 a$ & $3.29 c$ \\
\hline PSB-3 & $30.81 \mathrm{ab}$ & $0.161 \mathrm{e}$ & $3.73 a b$ \\
\hline PSB-4 & $34.45 a$ & $0.380 \mathrm{c}$ & 3.70ab \\
\hline PSB-6 & $26.44 b c$ & $0.374 c$ & $3.57 \mathrm{bc}$ \\
\hline PSB-8 & $25.76 b c$ & $0.381 \mathrm{c}$ & $3.35 c$ \\
\hline PSB-7 & $23.37 c$ & $0.418 b$ & $3.43 \mathrm{bc}$ \\
\hline PSB-12 & $34.68 a$ & $0.372 c$ & $3.96 \mathrm{bc}$ \\
\hline PSB-15 & $28.15 b c$ & $0.189 \mathrm{e}$ & $3.61 \mathrm{bc}$ \\
\hline PSB-16 & $24.08 c$ & $0.270 \mathrm{~d}$ & $3.96 a$ \\
\hline PSB-17 & $13.89 \mathrm{~d}$ & $0.486 \mathrm{bc}$ & $3.59 \mathrm{bc}$ \\
\hline Significance & $* * *$ & $* * *$ & $* *$ \\
\hline CV\% & 10.02 & 5.76 & 4.71 \\
\hline
\end{tabular}

CV: Coefficient Variance, Significance at $P<0.05=^{*}$, Significance at $P<0.01=^{* *}$ Significance at $\mathrm{P}<0.001=* * \star$, NS: Not Significant (Mean values along each column shown by same letter is not significantly difference at $P>0.05$ level)

Table 1: Amount of phosphorus solubilized by isolates, bacterial growth and $\mathrm{pH}$ variation in 1 st and 3rd day after inoculation. 
Citation: Rhan H, Walpola BC (2017) Brief In Vitro Analysis on Improvement of Available Phosphorous In Low Soluble Eppawala Rock Phosphate. J Microb Biochem Technol 9:105-108. doi: 10.4172/1948-5948.1000351

contain of $29 \%$ of phosphous although TSP containing $50 \%$ of $\mathrm{P}_{2} \mathrm{O}_{5}$ and Single super phosphate containing $18 \%$ of phosphorus and according to ERP contains $12 \%$ total P and $1.59 \%$ citric acid soluble P according to the vando molybdate method $[21,28]$. But in this experiment all the strains in day $1,3,5,7$ was significantly different $(\mathrm{P}<0.001)$ and there solubilized $\mathrm{P}$ was ranged from $7.61 \mathrm{ppm}-237.61 \mathrm{ppm}$

With the time period almost all bacterial strains has shown improvement of solubilized $\mathrm{P}$ in the culture media (Figures 1 and 2).

When consider the bacterial growth with the $\mathrm{pH}$ variation according to Figure 1 it shows polynomial relationship with the $\mathrm{R} 2=0.295$. So there is no relationship between $\mathrm{pH}$ variation and bacterial growth in

\begin{tabular}{|c|c|c|c|}
\hline & $\mathbf{P}$ & Growth & $\mathrm{pH}$ \\
\hline \multicolumn{4}{|l|}{ Day 5} \\
\hline PSB-1 & 188.06a & $0.730 \mathrm{~b}$ & $3.14 \mathrm{e}$ \\
\hline PSB-3 & $121.62 \mathrm{~cd}$ & $0.180 \mathrm{~h}$ & $3.49 \mathrm{bc}$ \\
\hline PSB-4 & 100.22ef & $0.415 f$ & $3.29 d$ \\
\hline PSB-6 & $166.66 b$ & $0.571 \mathrm{~d}$ & $3.48 \mathrm{bc}$ \\
\hline PSB-7 & $134.68 \mathrm{c}$ & $0.913 a$ & $3.42 \mathrm{c}$ \\
\hline PSB-8 & $179.95 a b$ & $0.502 e$ & $3.28 d$ \\
\hline PSB-12 & $91.66 f$ & $0.418 f$ & $3.18 \mathrm{e}$ \\
\hline PSB-15 & $87.16 f$ & $0.215 h$ & $3.29 d$ \\
\hline PSB-16 & $70.27 \mathrm{~g}$ & $0.323 g$ & $3.63 a$ \\
\hline PSB-17 & 111.48de & $0.635 c$ & $3.53 b$ \\
\hline Significance & $* \star *$ & $* * *$ & $* * *$ \\
\hline CV\% & 7.39 & 5.05 & 1.49 \\
\hline \multicolumn{4}{|c|}{ Day 7} \\
\hline PSB-1 & $173.42 \mathrm{c}$ & $1.28 a$ & $3.19 f$ \\
\hline PSB-3 & $106.53 e$ & $0.613 c$ & $3.57 c$ \\
\hline PSB-4 & $105.85 \mathrm{e}$ & $0.242 e$ & $3.41 \mathrm{e}$ \\
\hline PSB-6 & $187.16 \mathrm{bc}$ & $0.949 b$ & $3.63 \mathrm{bc}$ \\
\hline PSB-7 & $237.61 a$ & $1.18 a$ & $3.58 d$ \\
\hline PSB-8 & $173.43 c$ & $0.927 b$ & 3.46de \\
\hline PSB-12 & $124 d$ & $0.420 \mathrm{~d}$ & $3.42 \mathrm{e}$ \\
\hline PSB-15 & $92.11 \mathrm{e}$ & $0.336 \mathrm{de}$ & $3.50 \mathrm{~d}$ \\
\hline PSB-16 & $66.89 f$ & $0.329 \mathrm{de}$ & $3.86 a$ \\
\hline PSB-17 & $101.35 \mathrm{e}$ & $0.926 b$ & $3.67 b$ \\
\hline Significance & $* * *$ & $* * *$ & $* * *$ \\
\hline CV\% & 6.32 & 8.41 & 1.09 \\
\hline
\end{tabular}

CV: Coefficient Variance, Significance at $\mathrm{P}<0.05=^{*}$, Significance at $\mathrm{P}<0.01=^{* *}$

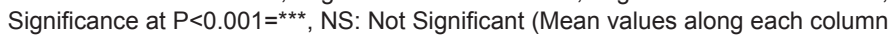
shown by same letter is not significantly difference at $\mathrm{P}>0.05$ level)

Table 2: Amount of phosphorus solubilized by isolates, bacterial growth and $\mathrm{pH}$ variation in 5 th and 7 th day after inoculation

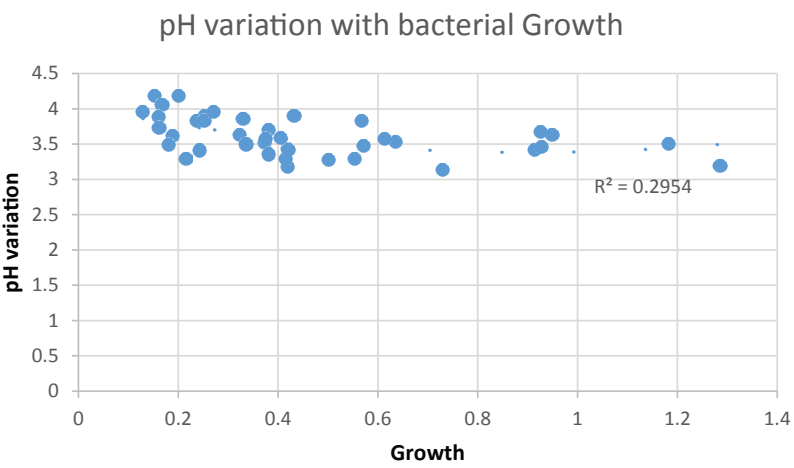

Figure 1: Relationship between bacterial growth and $\mathrm{pH}$ variation in ERP medium.

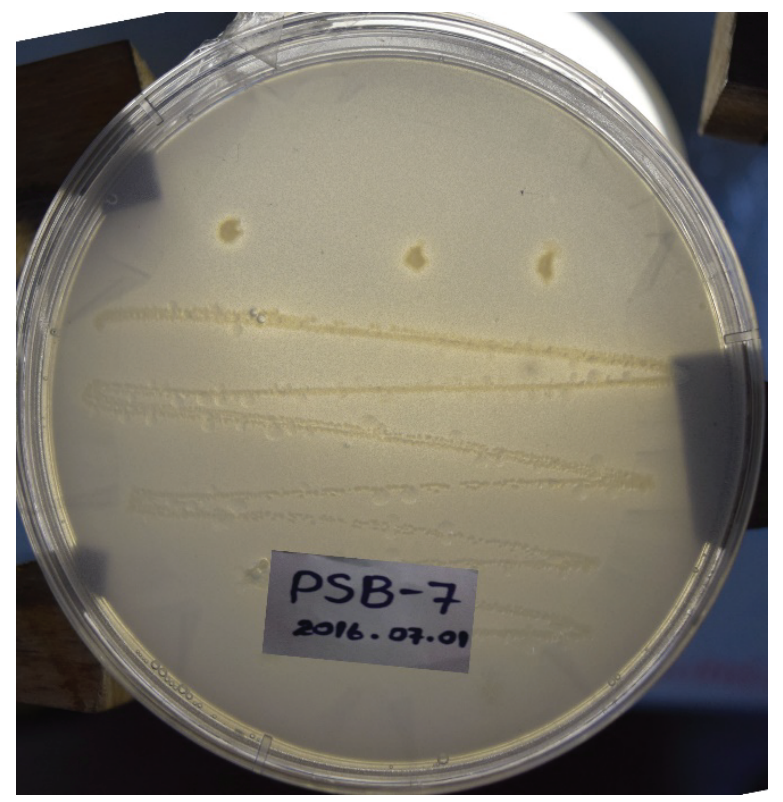

Figure 2: Halo zone produced by PSB in the Tri Calcium Phosphate containing NBRIP medium.

the ERP medium. In the day 7 lowest $\mathrm{pH}$ in the ERP enriched growth medium has showed by PSB-12 and PSB-4.

Within the whole experiment period there was significance change of $\mathrm{pH}(\mathrm{P}>0.001)$ could be identified. The bacterial growth changes initial $\mathrm{pH} 7.0$ to a normally $\mathrm{pH}$ 5.5-2.2 of the growth broth medium which includes ERP.

\section{Conclusion}

Despite of Environment unfriendly chemical Solubilization methods of naturally existing RP biological solubilization generate drastically higher amount of plant available phosphorous. PSB-7 strain has shown a vigorous growth and maximum P Solubilization 237.61 ppm in vitro during this experiment. The sedimentary phosphate deposit can be utilized under environment friendly Biological Phosphorous Solubilization by PSB. This biological method also treating the problem of rapid fixation of soluble inorganic phosphate added to soil soon after application.

\section{References}

1. Van Straaten P (2002) Rocks for crops: Agrominerals of sub-Saharan Africa Nairobi, Kenya Icraf.

2. Gedera HMT (1995) Attributes and the potential to acidulate eppawala apatite (Doctoral dissertation, University Of Peradeniya).

3. Hart EB, Phillips PH, Bohstedt G (1934) Relation of soil fertilization with superphosphates and rock phosphate to fluorine content of plants and drainage waters. Am J Public Health Nations Health 24: 936-940.

4. Khan AA, Jilani G, Akhtar MS, Naqvi SMS, Rasheed M (2009) Phosphorus solubilizing bacteria: occurrence, mechanisms and their role in crop production. Res Environ 2: 80-85.

5. Belimov AA, Hontzeas N, Safronova VI, Demchinskaya SV, Piluzza G, et al. (2005) Cadmium-tolerant plant growth-promoting bacteria associated with the roots of Indian mustard (Brassica juncea L Czern) Soil Biol Biochem 37: 241-250.

6. Madhaiyan M, Poonguzhali S, Sa T (2007) Metal tolerating methylotrophic bacteria reduces nickel and cadmium toxicity and promotes plant growth of tomato (Lycopersicon esculentum L) Chemosphere 69: 220-228. 
Citation: Rhan H, Walpola BC (2017) Brief In Vitro Analysis on Improvement of Available Phosphorous In Low Soluble Eppawala Rock Phosphate. J Microb Biochem Technol 9:105-108. doi: 10.4172/1948-5948.1000351

7. Babich H, Stotzky G (1977) Sensitivity of various bacteria, including actinomycetes and fungi to cadmium and the influence of $\mathrm{pH}$ on sensitivity. Appl Environ Microbiol 33: 681-695

8. Gunasekera R, Jayasekera S, Dissanayake T, Dissanayake (1991) Clonal differences in rock phosphate utilization by Hevea. Rubb Res Inst Sri Lanka 72: $15-26$.

9. Kucey RMN (1983) Phosphate-solubilizing bacteria and fungi in various cultivated and virgin Alberta soils. Canadian Journal of Soil Science 63: 671678.

10. Piccini D, Azcon R (1987) Effect of phosphate-solubilizing bacteria and vesicular-arbuscular mycorrhizal fungi on the utilization of Bayovar rock phosphate by alfa-alfa plants using a sand-vermiculite medium. Plant and Soil 101: 45-50.

11. Igual J, Valverde A, Cervantes E, Velázquez E (2001) Phosphate-solubilizing bacteria as inoculants for agriculture: Use of updated molecular techniques in their study. Agronomie 21: 561-568.

12. Kumari PDSU, Nanayakkara CM (2012) Screening of efficient phosphate solubilizing microorganisms from rhizosphere of some exports agricultural crops. In Annual Research Symposium.

13. Ranaweera SRM, Nanayakkara CM, Tennakoon NA (2012) Comparison of the effects of organic fertilizers with inorganic fertilizers on the growth of eight months old coconut seedlings and the nutrient availability and soil.

14. Jayawardana D, Ishiga HPH. Geochemical assessment of arsenic and selected trace elements in agricultural and non-agricultural soils of Sri Lanka. Tropical Agriculturist 160.

15. Han HS, Lee KD (2006) Effect of co-inoculation with phosphate and potassium solubilizing bacteria on mineral uptake and growth of pepper and cucumber. Plant Soil and Environment 52: 130-136.

16. Toro M, Azcón R, Barea JM (1998) The use of isotopic dilution techniques to evaluate the interactive effects of Rhizobium genotype, mycorrhizal fungi, phosphate-solubilizing rhizobacteria and rock phosphate on nitrogen and phosphorus acquisition by Medicago sativa. New Phytologist 138: 265-273.

17. Kumari MS, Ushakumari K (2002) Effect of vermicompost enriched with rock phosphate on the yield and uptake of nutrients in cowpea (Vigna unguiculata L. Walp) J Trop Agric 40: 27-30.
18. Ouahmane L, Thioulouse J, Hafidi M, Prin Y, Ducousso M, et al. (2007) Soil functional diversity and $P$ solubilization from rock phosphate after inoculation with native or allochtonous arbuscular mycorrhizal fungi. Forest Ecol Manag 241: 200-208.

19. Ivanova R, Bojinova D, Nedialkova K (2006) Rock phosphate solubilization by soil bacteria. J Univer Chem Technol Metal 41: 297-302.

20. Kumari U, Nanayakkara CM, Bandara U (2012) Development of a fungal inoculum for efficient phosphate utilization in agriculture. In Proceedings of International Forestry and Environment Symposium.

21. Pathirana LSS, Waidyanatha UDS, Peiris OS (1990) Utilization of phosphorus from apatite and growth of plants inoculated with vesicular arbuscular mycorrhiza and phosphate dissolving bacteria. J Rubb Res Inst. Sri Lanka70: 35-43.

22. McGill WB, Cole CV (1981) Comparative aspects of cycling of organic C, N, S and $\mathrm{P}$ through soil organic matter. Geoderma 26: 267-286.

23. Walpola BC, Arunakumara U, Yoon MH (2014) Isolation and characterization of phosphate solubilizing bacteria (Klebsiella oxytoca) with enhanced tolerant to environmental stress. Afric J Microb Res 8: 2970-2978.

24. Walpola BC, Yoon MH (2013) Isolation and characterization of phosphate solubilizing bacteria and their co-inoculation efficiency on tomato plant growth and phosphorous uptake. Afric J Microb Res 7: 266-275.

25. Bashan Y, Kamnev AA, de-Bashan LE (2013) Tricalcium phosphate is inappropriate as a universal selection factor for isolating and testing phosphatesolubilizing bacteria that enhance plant growth: A proposal for an alternative procedure. Biol fertil soils 49: 465-479.

26. SAS (2004) SAS/STAT User's Guide Version 9.1. SAS, Cary, NC

27. Nakamura S, Fukuda M, Nagumo F, Tobita S (2013) Potential utilization of loca phosphate rocks to enhance rice production in Sub-Saharan Africa. Japan Agricultural Research Quarterly 47: 353-363.

28. Wimalawansa SA, Wimalawansa SJ (2015) Protection of watersheds and control and responsible use of fertilizer to prevent phosphate eutrophication of reservoirs. Intern J Res Environ Sci 1: 1-18.
Citation: Rhan H, Walpola BC (2017) Brief In Vitro Analysis on Improvement of Available Phosphorous In Low Soluble Eppawala Rock Phosphate. J Microb Biochem Technol 9:105-108. doi: 10.4172/1948-5948.1000351

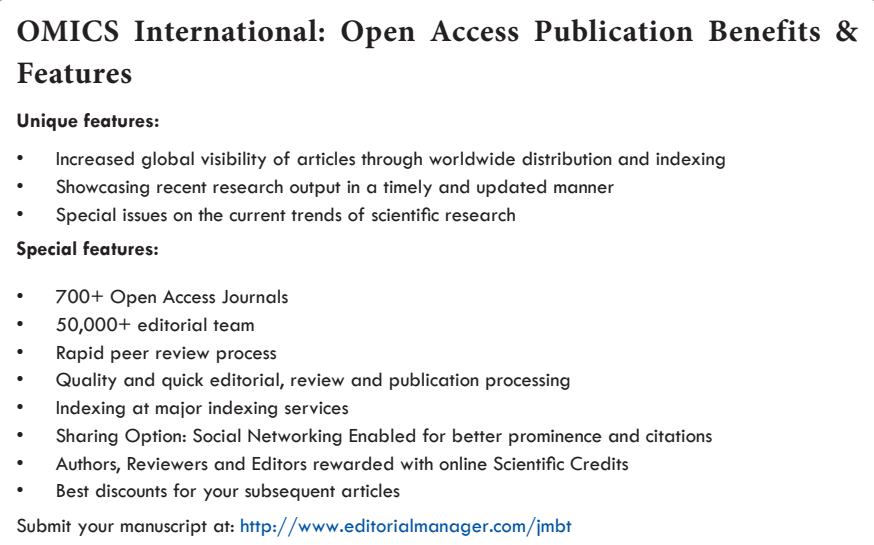

